\title{
Hyponatremia, bone mineral density and falls in the elderly; Results from AHAP study
}

\author{
SEYED REZA HOSSEINI ${ }^{1}$, NAGHI BAGHITABAR ${ }^{2}$, ALI MIRZAPOUR $^{2}$, \\ FARSHID OLIAEI $^{3}$, HAJIGHORBAN NOOREDDINI ${ }^{2}$, ALI BIJANI $^{1}$, SIMIN MOUODI $^{1}$ \\ ${ }^{1}$ Social Determinants of Health Research Center, Health Research Institute, Babol University of Medical Sciences, Babol, Iran \\ ${ }^{2}$ Faculty of Medicine, Babol University of Medical Sciences, Babol, Iran \\ ${ }^{3}$ Department of Internal Medicine, Babol University of Medical Sciences, Babol, Iran
}

\begin{abstract}
Background. Hyponatremia $(\mathrm{HN})$ can be associated with osteoporosis, falls and bone fractures in the elderly. Recent researches demonstrated different results about the correlation of $\mathrm{HN}$ with bone mineral density and bone fractures.

Methods. This analytic research came from the AHAP project in northern IRAN. All people aged 60 years and over were included in the study. Individuals with severe comorbidities and then who had concurrent conditions which could have impact on bone mineral densities (BMD) such as long-term use of steroids, calcium and/or vitamin D supplements, bisphosphonates, calcitonin, thiazides and hormonal medications were excluded.

Results. One thousand and one hundred and thirteen older persons entered in the study. More than 10 percent of the participants had $\mathrm{HN}$ (serum Na+ level $\leq 137 \mathrm{mEq} / \mathrm{L}$ ). No significant difference has been observed between hyponatremic and nonhyponatremic individuals about their balance abilities; bone mineral density; incidence of falls and/or bone fracture during the previous 6 months; dependency in activities of daily living; and osteoporosis.

Conclusion. HN was not a prevalent problem in older adults who met the inclusion criteria of this research. No significant difference has been observed between $\mathrm{HN}$ and bone mineral density and falls in the elderly.
\end{abstract}

Key words: Hyponatremia, Bone mineral density, Bone fracture, Osteoporosis, Aging.

\section{INTRODUCTION}

Hyponatremia $(\mathrm{HN})$ is a prevalent problem in the elderly [1-3]. Chronic diseases [3, 4] and concurrent use of certain medications such as diuretics [5] and antidepressants [6] put older people at greater risk of HN. Recent studies demonstrate that $\mathrm{HN}$ can be associated with osteoporosis, falls and fractures [1, 7-11]. The association of $\mathrm{HN}$ with falls and fractures might be independent of osteoporosis [12]. A case-control study conducted in the USA showed that chronic and recent $\mathrm{HN}$ were associated with osteoporosis $(\mathrm{OR}=12.09$, CI: 9.34-15.66) and fractures of extremities, pelvis or vertebrae $(\mathrm{OR}=4.61, \mathrm{CI}: 4.15-5.11)$ [9], while, another study conducted in the Netherlands represented that HN was not associated with lower bone mineral density (BMD), but it was associated with increased risk of nonvertebral bone fractures [11]. Other study conducted in the University of Michigan showed that hip osteoporosis occurred in $17.6 \%$ of patients with $\mathrm{HN}$ as compared to $6.6 \%$ of patients with normal serum sodium level, but osteoporosis was higher in younger age group (less than 55 years) as compared to older adults [13]. Considering different results in previous studies which may be due to the region where study participants were living and different underlying conditions; outcome variables which have been measured in the study protocol; and cut-off points of serum sodium concentration for determination of $\mathrm{HN}$, this research has been proposed to assess the association of $\mathrm{HN}$ with bone density and falls in older population of Amirkola, Northern Iran.

\section{MATERIALS AND METHODS}

This analytic research came from the Amirkola Health and Ageing Project (AHAP) [14]. All people aged 60 years and over were included in this study. Exclusion criteria were serious disease which did not permit to the elderly to follow the study examinations, and concurrent conditions which could have impact on bone mineral density such as longterm use of steroids at least for one month, calcium 
and/or vitamin D supplements, bisphosphonates, calcitonin, thiazides and hormonal medications.

The collected data included age, gender, habitual behaviors (smoking, alcohol consumption, and physical activity); history of falls and bone fracture during the previous 6 months and the number of falls, if occurred; self-reported comorbid physical and mental disorders and medications they were currently taking. Weight and height were measured to calculate body mass index (BMI) as weight/(height $)^{2}$.

The participants' static and dynamic balance abilities were measured with Berg Balance Scale (BBS). This test has 14 items and a five-point scale, ranging from $0-4$. " 0 " indicates the lowest and " 4 " the highest level of function. The scores in the range of 41-56 suggest "low fall risk", 40-21 "medium fall risk" and 0-20 can be interpreted as "high fall risk" [15]. The validity and reliability of Persian version of this scale have been confirmed in Iran [16].

Data on physical activity was measured using Physical Activity Scale for Elderly (PASE) and was collected through interviews $[17,18]$. The validity and reliability of this questionnaire (Cronbach's alpha coefficient of 0.97) were evaluated in an Iranian study [19]. The total score for each individual was calculated as between 0 and 400; higher scores meant higher physical activity levels. In this research, the scores greater than 150 were considered as having physical activity $[20,21]$.

The number of daily living activities which the participants needed help for doing was measured with ADL (activities of daily living) index. This index includes bathing, dressing, toileting, transferring, continence, and eating for measurement of the severity of disability [22].

Bone mineral density (BMD) was measured with DXA (dual-energy x-ray absorptiometry scan), by Lexxos densitometer (made in France). DXA measurements were performed at the neck of left femoral bone and lumbar vertebrae (L2-L4) and the result was expressed as T-scores. T-scores indicate the number of standard deviations (SD) by which the bone mass value deviated from the mean of a group of young normal controls [12]. T-scores $\leq$ -2.5 SD suggest osteoporosis, $-2.5<\mathrm{T}$-score $\leq-1$ SD represent osteopenia; and T-scores greater than -1 can be defined as normal BMD [23].

Serum sodium concentration was assessed by photoelectric flame photometer device. Serum $\mathrm{NA}^{+}$ level $\leq 137 \mathrm{mEq} / \mathrm{L}$ was considered as HN [24].

Data analysis was performed with SPSS software version 18. Final results were presented as descriptive statistics (mean and SD) and analytic statistics derived from t-test, chi-square, and oneway ANOVA. Odds ratio (OR) was used to show the additive risk of main outcome measures (such as balance disturbance, falls, fractures and osteoporosis) in the patients with hyponatremia.

This research was approved in the Ethics Committee of Babol University of Medical Sciences as registration code of MUBABOL.REC.1394.62.

\section{RESULTS}

One thousand and one hundred and thirteen older persons ( $\geq 60$ years) were eligible and entered the study (68.9\% of total): $622(55.9 \%)$ male and $491(44.1 \%)$ female. One hundred and fifteen individuals $(10.3 \%)$ had $\mathrm{HN}$. The baseline characteristics of the participants divided into normal and abnormal serum sodium concentrations are presented in Table 1. Significant differences have been observed between the two groups about their serum potassium and BUN levels and the percent of hypertensive patients $(p<0.05)$. Nearly $2.5 \%$ of the participants had balance disorders.

Physical activity, the history of falls and bone fracture during the previous six months, disability in daily living activities, and presence of osteoporosis were compared between the two groups (with $\mathrm{HN}$ and without $\mathrm{HN}$ ). The results are presented in Table 2. No significant differences have been observed between the two groups in the occurrence of falls and/or bone fracture during the previous 6 months; dependency in activities of daily living; and osteoporosis $(p>0.05)$.

Serum sodium concentration has been compared among the three groups (normal, with osteopenia and osteoporotic patients) according to gender and their BMD T-scores. Results are presented in Table 3. Three hundred and eighty four persons $(34.5 \%)$ had osteoporosis. No significant difference has been observed between males and females about serum sodium concentration, according to their BMD T-scores $(\mathrm{p}>0.05)$.

The association between serum sodium level and balance test, the occurrence of falls and bone fracture during the previous six months and disability in daily living activities is presented in Table 4. Mean of serum sodium concentration had no significant difference between the elderly who had lower ability to balance $(p=0.97)$, the older people who had disability in daily living activity $(\mathrm{p}=0.56)$, the elderly who had falls $(p=0.16)$ or bone fracture $(\mathrm{p}=0.26)$ in the previous 6 months. 
Table 1

Baseline characteristics of the participants based on their serum sodium level

\begin{tabular}{|c|c|c|c|}
\hline \multirow[b]{2}{*}{ Variable } & \multicolumn{2}{|c|}{ Serum sodium concentration } & \multirow[b]{2}{*}{ p-value } \\
\hline & $\begin{array}{c}\leq 137 \mathrm{mEq} / \mathrm{L} \\
N=115\end{array}$ & $\begin{array}{c}>137 \mathrm{mEq} / \mathrm{L} \\
N=998\end{array}$ & \\
\hline Age & $68.6 \pm 6.8$ & $68.5 \pm 7.1$ & 0.83 \\
\hline Number (percent) with diabetes mellitus & $34(9.9)$ & $308(90.1)$ & 0.78 \\
\hline Number (percent) with hypertension & $58(8.6)$ & $613(91.4)$ & 0.02 \\
\hline Number (percent) with self-reported cardiovascular disorders & $27(10.0)$ & $244(90.0)$ & 0.82 \\
\hline Number (percent) with hepatic disorders & $2(10.0)$ & $18(90.0)$ & 0.96 \\
\hline Number (percent) with renal disorders & 0 & 0 & 0 \\
\hline Number (percent) with drug history of corticosteroids & $8(10.0)$ & $72(90.0)$ & 0.73 \\
\hline Number (percent) with history of hormone replacement therapy & $2(10.5)$ & $17(89.5)$ & 0.81 \\
\hline Mean of serum calcium level & $9.35 \pm 0.45$ & $9.24 \pm 0.43$ & 0.77 \\
\hline Mean of serum phosphorus level & $4.11 \pm 0.60$ & $3.92 \pm 0.60$ & 0.71 \\
\hline Mean of serum potassium level & $4.05 \pm 0.38$ & $4.19 \pm 0.26$ & $<0.001$ \\
\hline Mean of serum BUN & $19.43 \pm 6.47$ & $18.09 \pm 5.49$ & 0.004 \\
\hline Mean of serum creatinine & $1.02 \pm 0.26$ & $0.95 \pm 0.21$ & 0.19 \\
\hline Body Mass Index & $26.7 \pm 4.0$ & $27.3 \pm 4.7$ & 0.14 \\
\hline Berg Balance Scale score & $51.7 \pm 7.1$ & $51.6 \pm 6.2$ & 0.95 \\
\hline Femoral Bone Mineral Density & $0.84 \pm 0.2$ & $0.84 \pm 0.2$ & 1 \\
\hline Vertebral Bones Mineral Density & $0.87 \pm 0.2$ & $0.86 \pm 0.2$ & 0.55 \\
\hline
\end{tabular}

Table 2

Prevalence of disability, falls, bone fracture and osteoporosis based on serum sodium concentration

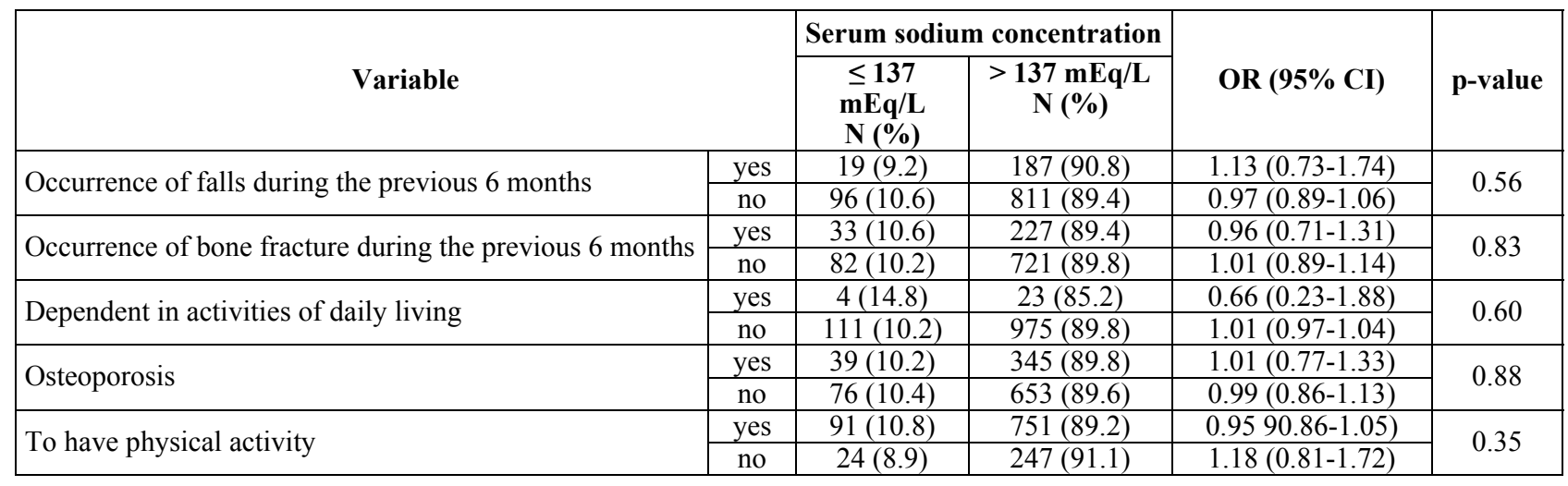

Table 3

Serum sodium concentration, Gender and Bone Mineral Density

\begin{tabular}{|c|c|c|c|c|}
\hline Gender & BMD groups & $\begin{array}{l}\text { Number of people } \\
\text { in this group }\end{array}$ & $\begin{array}{c}\text { Serum sodium concentration } \\
(\text { mean } \pm \text { SD })\end{array}$ & p-value \\
\hline \multirow{3}{*}{ Male } & Normal & 176 & $140.2 \pm 2.2$ & \multirow{3}{*}{0.33} \\
\hline & With Osteopenia & 347 & $140.3 \pm 2.5$ & \\
\hline & With Osteoporosis & 99 & $139.9 \pm 2.2$ & \\
\hline \multirow{3}{*}{ Female } & Normal & 52 & $140.5 \pm 2.0$ & \multirow{3}{*}{0.14} \\
\hline & With Osteopenia & 154 & $139.8 \pm 2.2$ & \\
\hline & With Osteoporosis & 285 & $140.2 \pm 2.5$ & \\
\hline \multirow{3}{*}{ Total } & Normal & 328 & $140.2 \pm 2.1$ & \multirow{3}{*}{0.82} \\
\hline & With Osteopenia & 501 & $140.1 \pm 2.4$ & \\
\hline & With Osteoporosis & 384 & $140.1 \pm 2.4$ & \\
\hline
\end{tabular}

Table 4

Serum sodium concentration, balance test, the history of falls and bone fracture and disability in daily living activities

\begin{tabular}{|c|c|c|c|c|}
\hline Variable & Groups & $\begin{array}{l}\text { Number of people } \\
\text { in this group }\end{array}$ & $\begin{array}{c}\text { Serum sodium concentration } \\
(\text { mean } \pm \text { SD })\end{array}$ & p-value \\
\hline \multirow{2}{*}{ Score of Berg Balance Test } & $<50$ & 271 & $140.1 \pm 2.4$ & \multirow{2}{*}{0.97} \\
\hline & $\geq 50$ & 842 & $140.1 \pm 2.3$ & \\
\hline \multirow{2}{*}{ Dependent in activities of daily living } & yes & 27 & $139.9 \pm 2.6$ & \multirow{2}{*}{0.56} \\
\hline & no & 1086 & $140.2 \pm 2.3$ & \\
\hline \multirow{2}{*}{ Occurrence of falls during the previous 6 months } & yes & 206 & $140.0 \pm 2.2$ & \multirow{2}{*}{0.16} \\
\hline & no & 907 & $140.2 \pm 2.4$ & \\
\hline \multirow{2}{*}{ Occurrence of bone fracture during the previous 6 months } & yes & 310 & $140.0 \pm 2.4$ & \multirow{2}{*}{0.26} \\
\hline & no & 803 & $140.2 \pm 2.3$ & \\
\hline
\end{tabular}




\section{DISCUSSION}

More than 10 percent of people aged 60 years and over had hyponatremia (serum $\mathrm{NA}^{+}$level $\leq$ $137 \mathrm{mEq} / \mathrm{L}$ ). No significant difference has been observed between hyponatremic and non-hyponatremic individuals about their balance abilities; bone mineral density; incidence of falls and/or bone fracture during the previous 6 months; dependency in activities of daily living; and osteoporosis. Mean of serum sodium concentration had no significant difference between the elderly who had lower physical activity; disability in daily living activity; and occurrence of falls or bone fracture in the previous 6 months. Considering BMD T-scores, no significant difference has been observed between two genders about their serum sodium concentration.

Nearly, one third of body sodium is stored in the bone [25]. The association of HN with balance impairment, falls and bone fractures in the elderly can be justified by different mechanisms including increase unsteady gait related to cognitive impairment; bone resorption and its fragility $[1,7,8,25]$, furthermore, another research presented that the sustained low extracellular sodium ion concentrations could directly stimulate osteoclastogenesis and that hyponatremia-induced oxidative stress might be involved in the mechanism [26].

In the research of Kinsella [12] which was conducted using the laboratory data related to 1408 females (aged 18 years and over, mean age of 61 years), $4.2 \%$ of the participants had serum sodium concentration less than $135 \mathrm{mEq} / \mathrm{L}$; $\mathrm{HN}$ was found in $8.7 \%$ of the patients who had previous bone fracture compared to $3.2 \%$ of subjects who did not have the history of fracture. Hyponatremic patients had a 2.86 fold increased OR for fracture occurrence which was a different result compared to the present study. In the research of Hoorn [11], consistent with our research, $\mathrm{HN}$ was not associated with lower BMD but it was associated with increased risk of bone fractures. Hoorn [11] and Usala [9] showed that more decline in serum $\mathrm{Na}^{+}$concentration may be needed to make osteoporosis in the elderly, while in our research mean of serum $\mathrm{Na}^{+}$concentration in the subjects with osteoporosis was $140.1 \pm 2.4$ (which is defined as nonhyponatremia). In Hoorn's study, individuals with HN had more recent falls $(23.8 \%$ versus $16.4 \%)$, which is different with our result. This difference may be attributed to study design and considering underlying causes of $\mathrm{HN}$ in the elderly; for example, we had excluded the people who consumed diuretics. These causes of $\mathrm{HN}$ can have more impact on falls and osteoporosis.
In the research of Karanchi [24] in which, similar to our study, serum $\mathrm{Na}^{+}$level $\leq 137 \mathrm{mEq} / \mathrm{L}$ was considered as cut-off point for $\mathrm{HN}$, it was presented that HN was associated with a three-fold increased risk of osteoporosis, which is different from our result; on the other hand, consistent with our study, there was no significant difference between hyponatremic and nonhyponatremic older adults about the recent bone fracture and BMD of hip and femoral bones. Also, in Karanchi's research, BMD was higher at lumbar vertebrae (L2-L4) of hyponatremic subjects. This difference in the results may be due to study designs; in our research, concurrent conditions which could have impact on BMD were considered as exclusive criteria, while in Karanchi's study, frail older adults entered in the research.

In our study, mean of serum $\mathrm{Na}^{+}$concentration in the three groups of BMD was about $140 \mathrm{mEq} / \mathrm{L}$ which is consistent with the studies of Hoorn [11] and Kinsella [12].

In the research of Usala in the USA [9], it was shown that $\mathrm{HN}$ was associated with chronic osteoporosis $(\mathrm{OR}=3.97)$, recent osteoporosis $(\mathrm{OR}=$ $3.06)$, chronic bone fractures $(\mathrm{OR}=4.61)$, and recent fractures $(\mathrm{OR}=3.05)$ which is different from our results. This difference may be attributed to study design and individual characteristics of participants.

In our study, no significant association has been observed between serum $\mathrm{Na}^{+}$concentration and incidence of falls; which is different with Ahamed's study in Australia [27]. Ahamed studied the patients aged $\geq 65$ years admitted with $\mathrm{HN}$ during a 6-month period and demonstrated the prevalence of $\mathrm{HN}$ as $22 \%$. In that research, $\mathrm{HN}$ was associated with the admission diagnoses of cardiovascular and metabolic disorders, use of diuretics and comorbidities. HN was associated with falls $(\mathrm{OR}=3.12)$, and the increased odds of falling were similar for mild and moderate to severe HN. Duration of patients follow-up and inclusion criteria of the study can be the causes of the difference in the results. In our study, the frail elderly who could not refer to undergo laboratory tests, or had comorbid disorders which could have impact on BMD such as long-term use of diuretics had been excluded.

In this study, serum potassium concentration was significantly lower in the patients who had lower serum sodium level; also, serum BUN was higher in this group. This result can be representative for the maintenance mechanism of serum sodium concentration in association to potassium and total body water [28-30]. Adrogué mentioned in his study 
that hyponatremia can be representative of excess of water relative to the sodium and potassium stores. Also, water retention usually results from impairment of renal excretion of electrolytes free water [29].

One of limitations of our study was that we examined recent $\mathrm{HN}$; not chronic $\mathrm{HN}$. It is suggested to be considered in future studies.

\section{CONCLUSION}

No significant difference has been observed between hyponatremia and bone mineral density and falls in the elderly. On the other hand, HN was not a prevalent problem in older adults who did not have serious comorbid disorder or severe disability or the individuals who did not consume medications which could have impact on serum sodium concentration.

\begin{abstract}
Acknowledgement. Hereby, the financial support of the ViceChancellor for Research and Technology of Babol University of Medical Sciences, and the kind cooperation of the elderly population of Amirkola to participate in the project are greatly appreciated.
\end{abstract}

Conflict of interest. The authors declare that there are no conflicts of interest.

Introducere. Hiponatremia (HN) se poate asocia cu osteoporoză şi cu fracturi în cadrul populației vârstnice. Mai multe studii recente au arătat legătura dintre $H N$ şi densitatea osoasă şi fracturile.

Metode. A fost realizat un studiu analitic cuibărit în cadrul cohortei AHAP din nordul Iranului. Toți pacienții peste 60 de ani au fost incluşi în studiu. Au fost excluşi indivizii cu comorbidități severe precum şi cei care ar putea fi avut anumite condiții ce ar fi interferat cu densitatea mineral-osoasă cum ar fi consumul de glucocorticoizi, suplimentare cu calciu/vitamina D, terapie cu bisfosfonați, calcitonină, tiazide precum şi medicație hormonală.

Rezultate. 1113 de pacienți în vârstă de 60 ani și peste au fost recrutați. Mai mult de $10 \%$ au avut hiponatremie (niveluri serice ale $\mathrm{Na}+\leq 137 \mathrm{mEq} / \mathrm{L}$ ). Nu s-au găsit diferențe semnificative între pacienții hiponatremici şi cei normonatremici.

Concluzii. HN nu a avut o prevalență foarte mare la pacienții vârstnici care au îndeplinit criteriile de includere în studiu. Nu au fost găsite diferențe semnificative între $H N$ şi densitatea minerală sau fracturile la pacienții vârstnici.

Correspondence to: Dr. Simin Mouodi, MD, MPH, Social Determinants of Health Research Center, Health Research Institute, Babol University of Medical Sciences, Babol, Iran

E-mail:dr.mouodi@gmail.com

\section{REFERENCES}

1. AYUS JC., FUENTES NA., NEGRI AL., MORITZ ML., GIUNTA DH., KALANTAR-ZADEH K., et al. Mild prolonged chronic hyponatremia and risk of hip fracture in the elderly. Nephrol Dial Transplant. 2016; 31(10):1662-9.

2. ZAINO CJ., MAHESHWARI AV., GOLDFARB DS. Impact of mild chronic hyponatremia on falls, fractures, osteoporosis, and death. Am J Orthop (Belle Mead NJ). 2013;42(11):522-7.

3. VERBALIS JG., BARSONY J., SUGIMURA Y., TIAN Y., ADAMS DJ., CARTER EA., et al. Hyponatremia-induced osteoporosis. J Bone Miner Res. 2010;25(3):554-63.

4. GRAMMATIKI M., RAPTI E., MOUSIOLIS A., YAVROPOULOU M., KARRAS S., TSONA A., et al. Patient With Severe Hyponatremia Caused by Adrenal Insufficiency Due to Ectopic Posterior Pituitary Lobe and Miscommunication Between Hypothalamus and Pituitary: A Case Report. Medicine. 2016; 95(10):1-6.

5. LIAMIS G., FILIPPATOS TD., ELISAF MS. Thiazide-associated hyponatremia in the elderly: what the clinician needs to know. Journal of Geriatric Cardiology. 2016; 13:175-82.

6. SHAKIBAEI F., GHOLAMREZAEI A., ALIKHANI M., TALAEIZADEH K. Serum Sodium Changes in Fluoxetine Users at Different Age Groups. Iran J Psychiatry. 2010;5(3):113-6.

7. NEGRI AL., AYUS JC. Hyponatremia and bone disease. Rev Endocr Metab Disord. 2017; 18(1): 67-78.

8. AYUS JC., NEGRI AL., KALANTAR-ZADEH K., MORITZ ML. Is chronic hyponatremia a novel risk factor for hip fracture in the elderly? Nephrol Dial Transplant. 2012; 27(10):3725-31.

9. USALA RL., FERNANDEZ SJ., METE M., COWEN L., SHARA NM., BARSONY J, et al. Hyponatremia Is Associated With Increased Osteoporosis and Bone Fractures in a Large US Health System Population. J Clin Endocrinol Metab. 2015; 100(8):3021-31. 
10. JAMAL SA., ARAMPATZIS S., HARRISON SL., BUCUR RC., ENSRUD K., ORWOLL ES., et al. Hyponatremia and fractures: findings from the MrOS study. J Bone Miner Res. 2015; 30(6):970-5.

11. HOORN EJ., RIVADENEIRA F., VAN MEURS JB., ZIERE G., STRICKER BH., HOFMAN A., et al. Mild hyponatremia as a risk factor for fractures: the Rotterdam Study. J Bone Miner Res. 2011; 26(8):1822-8.

12. KINSELLA S., MORAN S., SULLIVAN MO., MOLLOY MG., EUSTACE JA. Hyponatremia independent of osteoporosis is associated with fracture occurrence. Clin J Am Soc Nephrol. 2010; 5(2):275-80.

13. AFSHINNIA F., SUNDARAM B., ACKERMANN RJ., WONG KK. Hyponatremia and osteoporosis: reappraisal of a novel association. Osteoporos Int. 2015; 26(9):2291-8.

14. HOSSEINI SR., CUMMING RG., KHEIRKHAH F., NOOREDDINI H., BAIANI M., MIKANIKI E., et al. Cohort profile: the Amirkola Health and Ageing Project (AHAP). International Journal of Epidemiology. 2014; 43:1393-1400.

15. PICKENBROCK HM., DIEL A., ZAPF A. A comparison between the Static Balance Test and the Berg Balance Scale: validity, reliability, and comparative resource use. Clin Rehabil. 2016; 30(3):288-93.

16. AZAD A., TAGHIZADEH G., KHANEGHINI A. Assessments of the reliability of the Iranian version of the Berg Balance Scale in patients with multiple sclerosis. Acta Neurol Taiwan. 2011; 20(1):22-8.

17. TAO Y., WANG L., DONG X., ZHENG H., ZHENG Y., TANG X., ZHAO Y., et al. Psychometric properties of the Physical Activity Scale for the Elderly in Chinese patients with COPD. Int J Chron Obstruct Pulmon Dis12. 2017; 12:105-14.

18. ISMAIL N., HAIRI F., CHOO WY., HAIRI NN., PERAMALAH D., BULGIBA A. The physical activity scale for the elderly (PASE): Validity and reliability among community-dwelling older adults in Malaysia. Asia Pac J Public Health. $2015 ; 27$ (8 suppl):625-725.

19. SALEHI L., SHOKRVASH B., JAMSHIDI E., MONTAZER A. Physical activity in Iranian older adults who experienced fall during the past 12 months. BMC Geriatrics 2014; 14(115).

20. LOGAN SL., GOTTLIEB BH., MAITLAND SB., MEEGAN D., SPRIET LL. The Physical Activity Scale for the Elderly (PASE) Questionnaire; Does It Predict Physical Health? International Journal of Environmental Research and Public Health. 2013; 10:3967-86.

21. GERGER ALLISON M. Choosing an optimal self-report physical activity measure for older adults: does function matter? Master Essay, University of Pittsburgh. 2014 , Available From: http://d-scholarship.pitt.edu/21485.

22. LAPLANTE MP. The classic measure of disability in activities of daily living is biased by age but an expanded IADL/ADL measure is not. The Journals of Gerontology Series B: Psychological Sciences and Social Sciences, Oxford University Press. 2010; 65B(6):720-32.

23. JAMEBOZORGI A., KAVOOSI A., SHAFIEE Z., KAHLAEE AH., RAEI M. Investigation of the prevalent fall-related risk factors of fractures in elderly referred to Tehran hospitals. Medical Journal of the Islamic Republic Of Iran. 2013; 27(1):23-30.

24. KARANCHI H., KLEPPINGER A., KENNY A. Hyponatremia Is Associated with Increased Odds of Osteoporosis in Frail Older Men and Women. Endocrine Society's $96^{\text {th }}$ Annual Meeting and Expo. Chicago: June 21-24, 2014. Presentation Number: SUN-0262, Available From: http://press.endocrine.org/doi/abs/10.1210/endo-meetings.2014.BCHVD.13.SUN-0262.

25. AFSHINNIA F., SUNDARAM B., ACKERMANN RJ., WONG KK. Hyponatremia and osteoporosis: reappraisal of a novel association. Osteoporos Int. 2015; 26(9):2291-8.

26. SUGIMURA Y. Secondary osteoporosis or secondary contributors to bone loss in fracture. Osteoporosis associated with chronic hyponatremia. Clin Calcium. 2013; 23(9):1293-8.

27. AHAMED S., ANPALAHAN M., SAVVAS S., GIBSON S., TORRES J., JANUS E. Hyponatraemia in older medical patients: implications for falls and adverse outcomes of hospitalisation. Intern Med J. 2014; 44(10):991-7.

28. STERNS R. Disorders of plasma sodium - causes, consequences, and correction. N Engl J Med. 2015; 372: 55-65.

29. ADROGUE HJ, MADIAS NE. The Challenge of Hyponatremia. J Am Soc Nephrol 2012; 23: 1140-8.

30. PADMA V, JAVID SM. Study of symptomatic hyponatremia in elderly patients. Int J Pharm Bio Sci, 2016; 7: 434-40.

Received June 24, 2017 